ISSN 2078-6441. Вісник Львівського університету. Серія географічна. 2014. Випуск 47. С. 42-49. Visnyk of the Lviv University. Series Geography. 2014. Issue 47. P. 42-49.

502.4

\author{
( \\ ндрій олков, лег опік \\ деський держ вний екологічний університет, \\ вул. ввівськ, 15, 65016, м. дес, кр їн
}

3 г льнено інформ цію щодо просторового розподілу природно-з повідного фонду кр їни. креслено основні проблеми, пов'яз ні з недоскон лим використ нням ресурсів природно3 повідного фонду. озглянуто критерії т пок зники, які використовують для оцінки ступеня 3 повідності території, висвітлено їхні основні перев ги т недоліки, сформов но відповідний 6 нк д них із з стосув нням -п кет MapInfo т побудов но тем тичні к рти. икон но порівняльний н ліз регіонів кр їни з різними пок зник ми природно-з повідного фонду. пров джено комплексний підхід до поєдн ння цих пок зників н підст ві використ ння кл стерного н лізу, що д ло змогу ре лізув ти комплексне зонув ння території кр їни 3 просторовим розподілом об'єктів природно-з повідного фонду.

лючові слов : пок зники з повідності, геоінформ ційні системи, кл стерний н ліз.

епоху тот льного пришвидшення темпів індустрі льного розвитку б г тьох кр їн світу т підвищення вимог до якості життя щор 3 кту льнішими ст ють пит ння збереження т поліпшення ст ну н вколишнього середовищ ( ) як необхідного чинник економічного, екологічного т соці льного розвитку будь-якої кр їни.

ех нізми регулюв ння нтропогенного впливу н у більшості вип дків є недост тньо дієвими, відсутність економічного стимулюв ння щодо $\mathrm{p}$ ціон ліз ції використ ння природних ресурсів, особливо в укр їнських ре ліях, робить цю проблему ще кту льнішою. оч 3 г лом у м сшт 6 х усієї пл нети є позитивні зрушення, і світов спільнот щор з ч стіше 3 зн ч є про в жливість і пріоритетність екологічних проблем. прикл д, ужиття з ходів, передб чених іотським протоколом, д ло змогу зменшити кількість н дходження п рникових г зів в тмосферне повітря, суворіше судове з конод вство сприяло зменшенню кількості вип дків розливів н фти у води світового оке ну. роте у світі б г то глоб льних екологічних проблем ще не вирішено.

дним $з$ дієвих комплексних з ходів поліпшення ст ну $є з$ повід ння природних територій т об'єктів, тобто взяття під охорону держ ви. е н йбільш вд лий підхід с ме з екологічних позицій, оскільки в цьому р зі не просто обмежують вплив н якусь одну зі скл дових екосистеми (водні ресурси, земля, н др т ін.), з безпечують збереження природного комплексу з г лом, зі всім внутрішніми вз ємозв'язк ми т скл довими. ей мех нізм д є змогу вирішув ти одр зу декільк 3 вд нь, дже 3 повідні території створюють не лише з метою збереження генофонду т природних л ндш фтів, й для їхнього под льшого н укового вивчення т використ ння у просвітницькій і екотуристичній діяльності.

(C) олков ., опік ., 2014 
цих позицій дуже в жливими є пит ння оцінки якісних т кількісних х р ктеристик природоохоронних територій, визн чення методик н д ння певним територіям ст тусу т р нгу з повідності з метою оптиміз ції системи упр вління об'єкт ми природно-з повідного фонду ( $\quad$ ), створення екомереж т поліпшення ст ну 3 вдяки збереженню особливо цінних природних екосистем.

роблемі ст новлення з повідної спр ви ( ) в кр їні присвячено б г то різном нітних пр ць [1-8, 10, 12-14], одн к досі не розроблено єдиної методики н н ціон льному рівні, як 6 х р ктеризув л природоохоронний об'єкт з різних позицій т н д в л вичерпну інформ цію щодо його якісних і кількісних х р ктеристик.

йбільш поширеними дослідженнями в г лузі $\epsilon$ оцінк природоохоронних територій з метою под льшої розбудови регіон льних $[8,12]$ т н ціон льних екомереж [2]. $\quad$ г то досліджень присвячено обговоренню т обгрунтув нню в жливості економічної скл дової в розвитку т ст новленні кр їни [14], н лізу системи фін нсув ння об'єктів [3] т можливості розвитку екотуристичної діяльності в меж х з повідних територій [5].

еякі дослідження визн ч ють суто юридичні спекти використ ння земель т особливості їхної пр вової охорони [7]. прикл д, дуже цік вим є розгляд пит ння щодо пр в вл сності н землі об'єктів , дже вони н леж ть до окремої к тегорії земель, що підляг ють спеці льному пр вовому регулюв нню 3 боку 3 конод вств [10].

г то досліджень присвячено оцінці репрезент тивності територій об'єктів

[8] т н явних у них природних рослинних і тв ринних угрупов нь [1]. жливою є т кож пр ця, присвячен комплексній оцінці природоохоронного об'єкт $\mathrm{T}$ пошуку способів оптиміз ції його використ ння [6].

Зн чимо, що розробк методик оцінки об'єктів і територій відбув ється дещо однобічно, і отрим ні результ ти досліджень згідно з н явними методик ми не $є$ бсолютними величин ми, які б д в ли об’єктивну оцінку ст ну природоохоронної території. прикл д, існує методик оцінки природоохоронної ефективності з повідних територій [13], як є доволі скл дною і м є в основі суто біологічне підгрунтя т не вр ховує, н ж ль, економічної т соці льної зн чущості об'єктів . ітчизняні втори розгляд ють т кож методичні спекти созологічної оцінки змін, що відбув ються у природних екосистем х, які перебув ють під охороною [4]. н слідок досліджень втори доходять висновків, що збереження н явного біорізном ніття можливе лише $з$ допомогою системи спеці льних, н уково обгрунтов них, регуляційних, підтримув льних, відновлюв льних і контрольних з ходів, водноч с огр ніз ційно-методичною основою т ких з ходів $є$ комплексний природоохоронний моніторинг біорізном ніття, який, відповідно, є комплексним орг ніз ційно-н уковим т упр влінським з ходом, що з безпечує зворотний зв'язок між процес ми, які відбув ються в природних екосистем х, і тими з вд ннями, які стоять перед людиною в спекті їхнього збереження й з безпечення норм льного функціонув ння.

тже, підходи до оцінки якісних т кількісних х р ктеристик об'єктів суттєво відрізняються з структурою і д ють різні результ ти, що свідчить про необхідність розробки нової уніфіков ної системи для отрим ння чіткішого уявлення про ст н т дин міку розвитку н регіон льному, н ціон льному бо міжн родному рівнях.

ш мет - н ліз пок зників, які використовують для оцінки природоохоронних об’єктів і територій р йону, т порівняльн х р ктеристик результ тів оцінки 
дміністр тивних обл стей кр їни з 2012 р., розр хов н н підст ві різних підходів і критеріїв.

к вихідні м тері ли використ но д ні про кількісні пок зники, отрим ні з екологічних п спортів регіонів кр їни, оприлюднених н офіційному веб-с йті іністерств екології т природних ресурсів кр їни [11].

цінку мережі природно-з повідного фонду викон но 3 допомогою визн чення комплексу критеріїв т різних пок зників [12]. еред н йбільш поширених і тих, які використовують у пр ктиці, виділяють т кі.

ідсоток з повідності території, бо пок зник з повідності ( ), тобто відношення площі природно-з повідного фонду певної території $S$ до її з г льної площі $S_{3 \text { г }}[6,12]$. озр ховують $з$ формулою

$$
=\frac{S}{S_{\text {зг }}} \times 100 \% .
$$

риродоохоронний індекс території $(P t)$ визн ч ють через співвідношення суми площ кожної к тегорії особливо охоронюв ної природної території ( ) певного регіону, помножених н коефіцієнт зн чимості цих об'єктів, поділеної н з г льну площу регіону $[2,12]$. бчислюють 3 формулою

$$
P_{t}=\frac{k_{A} \sum S_{A i}+k_{B} \sum S_{B i}+k_{C} \sum S_{C i}+\ldots+k_{Z} \sum S_{Z i}}{S_{t_{i}}},
$$

де $P t_{i}$ - природоохоронний індекс регіону; $A, B, C, \ldots Z-$ к тегорії $\quad ; S_{A i}, S_{B i}, S_{i}, \ldots$ $S_{Z i}$ - площі к тегорій $\quad, \Gamma ; k_{A}, k_{B}, k_{C}, \ldots k_{Z}$ - коефіцієнти зн чимості к тегорій ; $S t_{i}-3$ г льн площ території, г .

оефіцієнт зн чимості певної к тегорії $\quad K_{A}$ визн ч ють як співвідношення зг льної кількості у регіоні $N$ до кількості певної к тегорії $N_{A}$

$$
K_{A}=\frac{N}{N_{A}} .
$$

літер турі дуже поширеним є використ ння індексу розчленов ності (інсуляризов ності) території $[8,12]$, який відобр ж є розподіл у меж х певного регіону т свідчить про уст леність об'єктів - дн к специфікою цього пок зник є те, що для його розр хунку необхідно визн ч ти кількість об'єктів, площ яких - менше 50 г , т к зв ні нестійкі території. ур хув нням тем тики т м сшт бів цієї роботи ми вв ж ємо, що доцільніше використовув ти з мість індексу інсуляризов ності коефiцієнт інсуляризов ності I [6], який визн ч є співвідношення рівня фр гментов ності з повідних природоохоронних територій

$$
I=\frac{\sqrt{n^{2}+S^{2}}}{S_{\text {з г }}},
$$

де $n$ - кількість з повідно-територі льних одиниць; $S$ - сум рн площ природоохоронних територій, г ; $S_{3 \text { г }}-3$ г льн площ території, г .

скільки кожен із н ведених пок зників м є свої перев ги і недоліки, то отрим ння інтегр льної к ртини можливе з вдяки використ нню лгоритму, що д $\epsilon$ змогу об'єдн ти ці пок зники в комплексну векторну величину

$$
V_{i}\left({ }_{i}, P t_{i}, I_{i}\right),
$$

де $i$-номер дміністр тивного $\mathrm{p}$ йону. 
К т кий лгоритм доцільно з стосув ти лгоритм кл стерного н лізу (рис. 1), основні положення якого можн сформулюв ти т к [9].

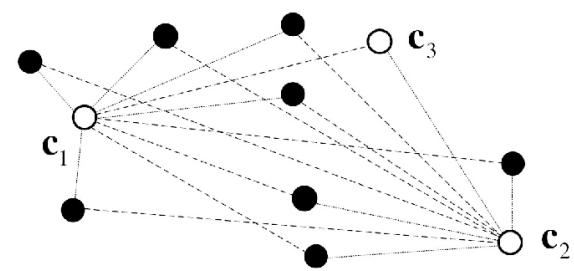

ис. 1. хем тичне зобр ження процесу кл стериз ції н прикл ді двовимірного простору
1. к перший центр кл стер обир ють елемент $c_{1}=x_{1}$.

2. к другий центр кл стер обир ють той елемент $c_{2}=x_{j 2}$, що $€ \mathrm{H}$ н йбільшій відст ні від $c_{1}$, тобто $\left\|x_{j 2}-c_{1}\right\|=\max _{x \in \Xi}\left\|x-c_{1}\right\|$.

3. рипустимо, що обр но $k$ центрів $C^{(k)}=\left\{c_{1}, \ldots, c_{k}\right\}$ кл стерів. к черговий $(k+1)$-й центр кл стер обир ють той елемент $x_{j k+1}$, що $є$ н н йбільшій відст ні від н йближчого до центрів $c_{1}, \ldots, c_{k}$, тобто $\min _{c \in C^{(k)}}\left\|x_{j k+1}-c\right\|=\max _{x \in \Xi \backslash C^{(k)}} \min _{c \in C^{(k)}}\|x-c\|$.

4. еревіряють умову “зупинки”. мовою “зупинки” лгоритму може бути викон ння нерівності $Q_{(k+1)} / Q_{(k)} \geq \gamma$, де $\gamma \in(0,1)$, тобто деякого порогового зн чення, близького до одиниці. икон ння ост нньої умови озн ч $є$, що в р зі появи нового центр кл стер дисперсія змінюється незн чно.

ля отрим ння гр фічного зобр ження просторового розподілу розглянутих пок 3ників зручно з стосув ти геоінформ ційний п кет MapInfo ( , Mapping nformation Systems Corp.), що ост нніми рок ми м є провідні позиції серед геоінформ ційних систем для персон льних комп'ютерів [15].

н слідок проведених розр хунків отрим но числові пок зники, які х р ктеризують ст н в кр їні. орівняльн х р ктеристик отрим них д них н веден в т блиці.

к б чимо з м тері лу, н йбільші зн чення з $з$ фіксов но в в но- $р$ нківській, мельницькій, к рп тській, ернівецькій т олинській обл стях, вони ст новлять $15,74,14,80,13,92,12,60$ і 10,90\%, відповідно, н йменші зн чення є у уг нській, ерк ській, ніпропетровській, рківській т інницькій обл стях - 3,29, 3,00, 2,35, 2,32, 2,07\%, відповідно.

йбільші зн чення пок зник $P t$ з реєстров но в мельницькій, к рп тській, ернігівській, в но- р нківській т ернопільській обл стях - відповідно, 69,92, $34,16,20,66,14,67,14,59$, н йменші зн чення є в уг нській, онецькій, рківській, иївській т ніпропетровській обл стях - 1,73, 1,57, 0,92, 0,82, 0,43, відповідно.

пок зником простежується т к ситу ція: н йбільші зн чення 3 фіксов но в в но- $\mathrm{p}$ нківській, мельницькій, к рп тській, ернівецькій т олинській обл стях - 0,16, $0,15,0,14,0,14,0,12$, відповідно. йменші зн чення є в уг нській, онецькій, ніпропетровській, рківській т інницькій обл стях - 0,03, 0,03, 0,02, 0,02, 0,02, відповідно.

зн чимо, що простежується чітк тенденція т деяке співвідношення в н ведених результ т х. прикл д, у першій п’ятірці н йбільші зн чення з всім пок зник ми м ють в но- $\mathrm{p}$ нківськ, мельницьк $\mathrm{T}$ к рп тськ обл сті. $\mathrm{K}$ ж ситу ція н іншому “полюсі”, тобто в н йменших зн ченнях. уг нськ, ніпропетровськ т

рківськ обл сті розміщені внизу порівняльної т блиці. я тенденція в розподілі зумовлен специфікою розр хунків т одн ковістю вихідних д них: передб ч ють, що в усіх розр хунк х фігурують тільки дв п р метри - площ територій і кількість 
орівняльн х р ктеристик індексів оцінки

\begin{tabular}{|c|c|c|c|}
\hline \multirow{2}{*}{ егіон кр їни } & \multicolumn{3}{|c|}{ ок зник } \\
\hline & & $P t$ & $I$ \\
\hline в но- $\mathrm{p}$ нківськ обл. & 15,74 & 14,67 & 0,16 \\
\hline мельницьк обл. & 14,80 & 69,92 & 0,15 \\
\hline к рп тськ обл. & 13,92 & 34,16 & 0,14 \\
\hline ернівецьк обл. & 12,60 & 11,58 & 0,14 \\
\hline олинськ обл. & 10,90 & 8,53 & 0,12 \\
\hline ерсонськ обл. & 7,80 & 2,68 & 0,10 \\
\hline ернопільськ обл. & 8,87 & 14,59 & 0,10 \\
\hline івенськ обл. & 9,05 & 10,51 & 0,09 \\
\hline ернігівськ обл. & 7,60 & 20,66 & 0,08 \\
\hline рим & 8,31 & 2,04 & 0,08 \\
\hline ьвівськ обл. & 6,72 & 5,45 & 0,07 \\
\hline умськ обл. & 7,40 & 12,88 & 0,07 \\
\hline порізьк обл. & 4,50 & 5,71 & 0,06 \\
\hline деськ обл. & 4,52 & 3,28 & 0,05 \\
\hline олт вськ обл. & 4,95 & 3,38 & 0,05 \\
\hline итомирськ обл. & 4,50 & 1,93 & 0,05 \\
\hline іровогр дськ обл. & 4,14 & 3,43 & 0,04 \\
\hline иївськ обл. & 4,01 & 0,82 & 0,04 \\
\hline икол ївськ обл. & 4,10 & 1,84 & 0,04 \\
\hline ерк ськ обл. & 3,00 & 5,06 & 0,03 \\
\hline уг нськ обл. & 3,29 & 1,73 & 0,03 \\
\hline онецьк обл. & 3,46 & 1,57 & 0,03 \\
\hline ніпропетровськ обл. & 2,35 & 0,43 & 0,02 \\
\hline рківськ обл. & 2,32 & 0,92 & 0,02 \\
\hline інницьк обл. & 2,07 & 3,03 & 0,02 \\
\hline
\end{tabular}

я регіон льн нерівномірність кількості природоохоронних територій т об'єктів н 3 ході й сході с м по собі є в гомою проблемою, дже природні л ндш фти - це унік льні утворення, і збереження великих площ в одному регіоні не компенсує їхнього дефіциту т інтенсивного техногенного н в нт ження н них в іншому.

ок зник з повідності, як один з н йпримітивніших в рифметичному сенсі критеріїв оцінки ст ну з повідності території, дуже ч сто з зн є жорсткої критики з боку 6 г тьох спеці лістів. сновним його недоліком $\epsilon$ нерепрезент тивність, дже не вр ховують д них про типи біогеоценозів у меж х певної з повідної території [1], тому результ ти його розр хунку вв ж ють суто дміністр тивним пок зником для форм льної оцінки площ земельних угідь, з йнятих під об'єкти

риродоохоронний індекс регіону є більш обгрунтов ним у н уковому сенсі пок зником т м є скл дніший лгоритм розр хунку. жливий момент у р зі його використ ння - ур хув ння коефіцієнт зн чимості, який є своєрідною б льною оцінкою певної к тегорії , проте визн чений не умоглядно, н підст ві об'єктивних співвідношень кількості т площ об'єктів певного р нгу і їхньої з г льної кількості, дже площ будь-якої - це функція іiі біологічного т л ндш фтного різном ніття, тому є не лише кількісною, й якісною х р ктеристикою [2]. дн к і цей метод не доскон лий. еякі втори з зн ч ють, що він $є$ дещо форм лізов ним і недост тньо 
інформ тивним, оскільки розгляд є

як єдину однорідну структуру [1]. кож не зовсім доскон лим є коефіцієнт зн чимості. к виплив є з тр ктув ння втор [2], у p зі його розр хунку вр ховують з г льну кількість в кр їні т кількість певної к тегорії, тобто він є одн ковим для всіх р йонів, змінюється лише площ території. и цю методику скоригув ли і в ході розр хунку вр ховув ли з г льну кількість в регіоні т кількість певної к тегорії. цьому р зі з г льн тенденція, н яку спир ються, порівнюючи укр їнський і європейський підходи [2], зберіг ється, у вип дку розр хунку для кожної конкретної дміністр тивної одиниці зн ходять в гові коефіцієнти, які вр ховують регіон льні особливості розподілу цього пок зник . оді можливі ситу ції, коли дв різні з р нгом , н прикл д, н ціон льний природний п рк т зоологічний п рк, м тимуть одн кові коефіцієнти зн чимості, одн к площі цих територій зн чно відрізнятимуться, і кінцеві зн чення відповід тимуть логічному розподілу, що д є підст ви говорити про об'єктивність методики.

тосовно коефіцієнт інсуляризов ності можуть виник ти деякі сумніви, дже суто рифметично він відрізняється від тр диційного індексу інсуляризов ності. роте отрим ні результ ти є досить однорідними т зберіг ють з г льну тенденцію, прит м нну іншим двом критеріям. озитивним моментом використ ння цього пок зник $є$ простот в розр хунк х, однорідність отрим них результ тів.

ля н очного відобр ження отрим них результ тів побудов но тем тичні к рти просторового розподілу пок зників з регіон ми кр їни у 2012 р. (рис. 2-4).

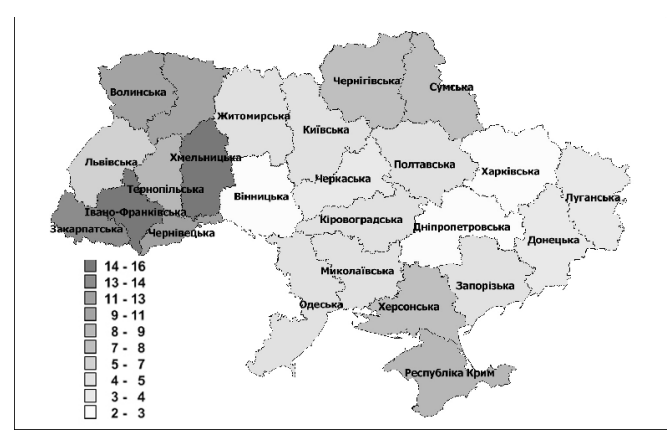

ис. 2. озподіл по регіон х кр їни

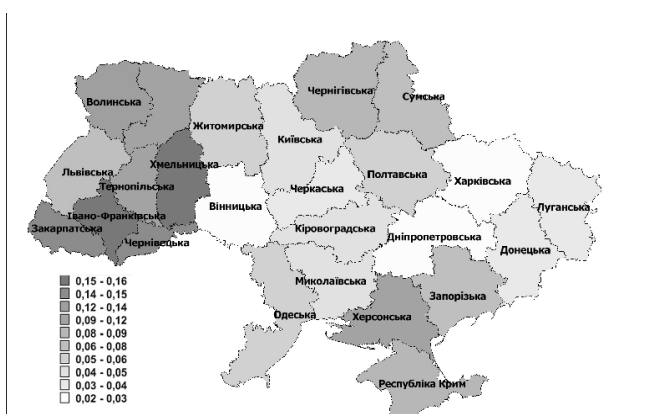

ис. 4. озподіл по регіон х кр їни

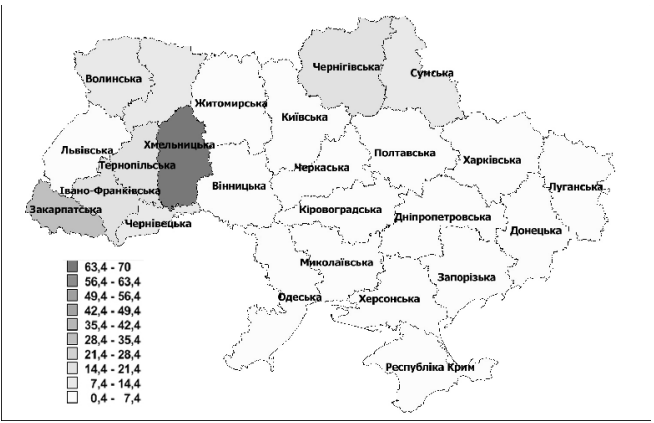

ис. 3. озподіл $P t$ по регіон х кр їни



ис. 5. езульт ти кл стерного н лізу p йонув ння території кр їни з величиною $V$ 
ост нньому ет пі викон но кл стерний н ліз території кр їни з використ нням векторної величини (5). н слідок проведення кл стерного н лізу отрим но п'ять кл стерів, що відобр ж ють р нжув ння регіонів кр їни 3 рівнем 3 повідності території. к 6 чимо з рис. 5, для отрим ного р йонув ння х $\mathrm{p}$ ктерн рівномірніш к ртин розподілення, тобто у кожен кл стер, з винятком першого, входять чотири чи більше обл стей.

тже, розр хов но три пок зники (,$P t$,$) , які х р ктеризують ст н в кр їні$ 32012 р., викон но порівняльний н ліз цих пок зників, виявлено позитивні т нег тивні моменти їхньго використ ння. підст ві отрим них д них побудов но тем тичні к рти, які н очно демонструють суч сний ст н розвитку в кр їні.

еоднозн чність підходів т висвітлені недоліки пок зників роблять неможливим формув ння єдиної системи поглядів н якісні т кількісні п р метри . к компроміс для отрим ння уз г льненої к ртини можн використ ти т кий підхід, як кл стерний н ліз, що д є змогу об'єдн ти всі пок зники в єдину векторну величину. роте всі підходи оцінюють лише просторовий розподіл об'єктів, , їню територі льну цілісність т однорідність, ле не д ють дет льної інформ ції про ст н конкретних об'єктів і територій, видовий скл д, не вр ховують в жливості певних предст вників флори і ф уни т цінності л ндш фтних комплексів з г лом.

1. тем сов . . епрезент тивность природных биогеоценозов в системе природных резерв тов к к индик тор эффективности территори льной охр ны природы / . . тем сов // повідн спр в в кр їні. - 2007. - № 1-2 (13). - . 1-6.


кр ины в спекте формиров ния н цион льных экосетей / . . л кберн, . . рпов // повідн спр в в кр їні. - 2009. - № 2 (15). - . 1-8.

3. нилов . . истем фін нсув ння розвитку природно-з повідного фонду кр їни: ст тистичний н ліз / . . нилов // існик . - 2008. - № 1 (43). . 251-256.

4. 2 ло . . етодичні спекти созологічної оцінки резерв тогенних змін біогеоценозів у системі екомережі т природно-з повідних територій / . . г ло, . . ижин // укові основи збереження біотичної різном нітності. $-2010 .-$. 1 (8), № 1. - . 9-28.

5. дніч нськ . собливості розвитку екотуризму у н ціон льних природних п рк х ьвівщини / . дніч нськ // існик ьвів. ун-ту. ер. міжн р. відносини. - 2008. - № 24. - . 101-105.

6. ов льчук . . риродно-з повідний фонд території ізоцького кряжу: суч сний ст н, його к ртогр фічн модель, шляхи оптиміз ції функціонув ння / . . ов льчук, . . ндрейчук, . . д нюк // рирод хідного олісся т прилеглих територій. - 2012. - № 9. - . 374-382.

7. овтун . . истем природно-з повідного з конод вств кр їни / . . овтун // існик к демії двок тури кр їни. - 2009. - № 2 (15). - . 43-49.

8. онякін . цінк репрезент тивності природно-з повідних територій як основи функціонув ння регіон льної екомереж ерк щини / . онякін // ук. вісн. ернів. ун-ту. - 2013. - № 614-615. - . 58-65. 
9. пский . тем тические методы р спозн в ния обр зов : курс лекций / . . пский, . . роневич. - г нрог : зд-во , 2009. - 155 с.

10. лярчук . . p во вл сності н земельну ділянку в контексті пр вового режиму земель природно-з повідного фонду т їх 3 хисту / . . лярчук, . . вчинников // рид. вісник. - 2013. - № 4 (13). - . 13-17.

11. іністерство екології т природних ресурсів кр їни: [ лектронний ресурс]. ежим доступу: http://www.menr.gov.ua.

12. илипенко . . цінк природно-з повідного фонду території дністров'я для обгрунтув ння регіон льної екологічної мережі / . . илипенко, . . одоров // еополитик и экогеодин мик регионов. - 2014 . - № 2 (10). - . 714-718.

13. тишов . . етодик оценки природоохр нной эффективности особо охр няемых природных территорий и их регион льных систем / . . тишов. - . : WWF оссии, 2012. -284 с.

14. кімчук . . кономічне стимулюв ння розвитку природно-з повідного фонду у контексті екологічної конституції емлі / . . кімчук // ук. вісн. ц. лісотехн. ун-ту кр їни. - 2006. - № 16.8. - . 172-182.

15. MapInfo Professional User Guide. - Stamford : Pitney Bowes MapInfo Corporation, 2007. -568 p.

m ття: н дійшл до ред кції 18.08.2014

доопр иьов н 11.09 .2014

прийнят до друку 15.10.2014

\section{COMPREHENSIVE ANALYSIS OF ADVANTAGES AND DISADVANTAGES OF ESTIMATION METHODS OF LAND CONSERVATION (USING GIS)}

\section{Andriy Volkov, Oleg Popik}

Odesa State Environmental University, Lvivska Str., 15, UA - 65016, Odesa, Ukraine

The research includes generalization and compilation of the information which concerns spatial distribution of Ukraine conservation areas. The vital problems concerned to ineffective usage of conservation areas were discussed.

The existing criteria and indexes which are used for assessing of natural conservation areas were discussed. The main advantages and disadvantages of the indexes were analyzed. The database and the thematic maps of conservation areas spatial distribution were designed utilizing geoinformational application MapInfo. Ukraine's regions were compared by different conservation area indexes. Comprehended approach to estimation of conservation areas was implemented based on cluster analysis. Complex zoning of Ukraine based on spatial distribution of conservation areas was offered.

Key words: conservation area indexes, geographic informational systems, cluster analysis. 